\title{
An advantageous level of irrigation water salinity for wheat cultivation
}

\author{
M. A. Mojid*, K. F. I. Murad, S. S. Tabriz and G. C. L. Wyseure ${ }^{1}$ \\ Department of Irrigation and Water Management, Bangladesh Agricultural University, Mymensingh-2202, \\ Bangladesh and ${ }^{1}$ Division of Land and Water Management, Department of Earth and Environmental Sciences, \\ Celestjnenlaan 200E, 3001 Leuven (Heverlee), Belgium, ‘E-mail: ma_mojid@yahoo.com
}

\begin{abstract}
Response of wheat (Triticum aestivum L., cv. Shatabdi) to irrigation water of five salinity levels was investigated at the Bangladesh Agricultural University (BAU) farm with a view to search for a possible advantageous salinity level for the crop. The experiment comprised five treatments $-\mathrm{I}_{1}$ : irrigation by fresh water of background salinity $0.385 \mathrm{dS} \mathrm{m}^{-1}$ (control) and $\mathrm{I}_{2}-\mathrm{I}_{5}$ : irrigation by synthetic saline water (prepared by mixing sodium chloride salt with fresh water) of electrical conductivity (EC) 4, 7, 10 and $13 \mathrm{dS} \mathrm{m}^{-1}$ (at $25^{\circ} \mathrm{C}$ ), respectively. Wheat was grown under three irrigations applied at maximum tillering, booting and milking/grain filling stages, and with recommended fertilizer dose. Irrigation water of $E C \geq 10 \mathrm{dS} \mathrm{m}^{-1}$ significantly $(p=0.05$ ) suppressed most growth and yield attributes, and yield of wheat compared to irrigation by fresh water $\left(I_{1}\right)$. An attention-grabbing observation was that irrigation by saline water of $4 \mathrm{dS}$ $\mathrm{m}^{-1}\left(\mathrm{I}_{2}\right)$ contributed positively to the crop attributes. Leaf area index (LAI), spike length, spikelets and grains per spike, 1000-grain weight and above ground dry matter (ADM) of wheat increased by 1.9-3.4, 0.9, 2.6, 7.4, 2.1 and 2.8-6.0\%, respectively in $\mathrm{I}_{2}$ compared to the control. The improvement in the LAI and ADM in $\mathrm{I}_{2}$ was significant over $\mathrm{I}_{1}$. Because of the largest spike density, the utmost grain $\left(3.85 \mathrm{t} \mathrm{ha}^{-1}\right)$, straw $\left(5.09 \mathrm{t} \mathrm{ha}^{-1}\right)$ and biomass $\left(8.93 \mathrm{t}\right.$ ha $\left.{ }^{-1}\right)$ yields of wheat were however obtained under $I_{1}$. The proposition of the advantageous irrigation water salinity level of $4 \mathrm{dS} \mathrm{m}^{-1}$ thus warrants further investigation.
\end{abstract}

Keywords: Irrigation water, Salinity level, Wheat yield

\section{Introduction}

Limited supplies of fresh water are now increasingly in demand for competing uses and creating the need to use marginal quality water, especially in agriculture (Hamdy, 1995; Mojid et al., 2012). Use of saline water for irrigation has the advantages of reducing fresh water requirement for salt-tolerant crops. But, salinity affects crops depending on its degree at critical growth stages and reduces the yield. So, irrigation by saline water needs to be controlled in an appropriate level for the specific crops. There is, however, no any single way to achieve the safe use of saline water in irrigation. Many different approaches and practices may need to be combined to develop satisfactory systems for saline water irrigation. An appropriate combination depends upon economic, climatic, social as well as edaphic and hydrogeologic situations (Rhoades et al., 1992). In general, crops tolerate salinity up to a threshold level, above which yields of the crops decrease, approximately linearly, as the salt concentration increases. Therefore, crop response to salinity levels is an important factor for irrigation by saline water. The use of marginal quality waters in irrigation requires careful planning, more complex management practices and stringent monitoring procedures than when good quality water is used (Hamdy, 1996; Rahman et al., 1995).

The effects of salinity and water stress are, generally, additives in their impacts on evapotranspiration of crops (Shalhevet, 1994). Salts in soil water reduce evapotranspiration by making the soil water less available for extraction by plant roots (Allen et al., 1998; Heidarpour et al., 2009). Salinity reduces plant growth by suppressing the rate of leaf elongation due to reduction of cell division and enlargement in leaves (Allen et al., 1998). Many plants are however able, by building up higher internal solute contents, to partially compensate for low osmotic potential of soil water under saline conditions (Allen et al., 1998). The inherent ability of the crops to withstand the effects of elevated salt concentration within their root zone solutions and still produce a reasonable quantity of agricultural product defines the magnitude of the crop tolerance or resistance to salinity (Steppuhn et al., 2005). Crops vary in their relative salt tolerance ability, and hence knowing their salt-tolerant limits and soil salinity levels, potential crops can be grown in saline area. The success of using saline water for economically viable crop production can be achieved by reducing the negative effects of salinity on crop productivity by following the best management practices (Flowers et al., 2005). For example, selection of the crops for their tolerance is an important aspect for the management of saline soils (Gupta and Gupta, 1987). 
Wheat is an important cereal crop that ranks first in acreage as well as production among the crops of the world (UNDP and FAO, 1988). Salinity exerts negative influences on wheat with an ultimate reduction in yield (Aldesuquy and Ibrahim, 2002; Ghane et al., 2011). In addition to yield reduction, Zaire and Khuble (1990) reported significant interactions between salinity and wheat cultivars. Yet, wheat may be grown effectively under irrigation by saline water if an optimum tolerable salinity for its cultivation can be established (Ghane et al., 2011). It is therefore important to identify the salt-tolerant level of wheat and its yield variation with salinity of irrigation water. This study investigated the effects of irrigation water salinity on growth and yield attributes, and yield of wheat with a view to search for an advantageous salinity level for the crop.

\section{Materials and Methods}

\section{Site characteristics}

The experiment was conducted during November 2010 to March 2011 in the experimental farm of Bangladesh Agricultural University, Mymensingh, Bangladesh. The site is situated at $24.75^{\circ} \mathrm{N}$ latitude and $90.50^{\circ} \mathrm{E}$ longitude. Silt loam underlain by sandy loam in the field belongs to the Old Brahmaputra floodplain (BARC, 2005). Organic matter content, field capacity, permanent wilting point and bulk density of the top soil were $0.48 \%, 38.19 \%(\mathrm{v} / \mathrm{v}), 18.37 \%(\mathrm{v} / \mathrm{v})$ and $1.33 \mathrm{~g} \mathrm{~cm}^{-3}$, respectively. Pre-sowing soil $\mathrm{pH}$ was $7.9,8.0$ and 8.2 for $0-20,20-40$ and $40-60 \mathrm{~cm}$ soil layer, respectively. Electrical conductivity, EC, of saturation extract (soil: water $=1: 2.5$ ) of the corresponding soil layer was $0.18,0.12$ and $0.08 \mathrm{dS} \mathrm{m}^{-1}$. Mean maximum and minimum air temperature at the site varied from 22.2 to $30.0^{\circ} \mathrm{C}$ and 10.7 to $20.0^{\circ} \mathrm{C}$, respectively. Mean relative humidity, pan evaporation and sunshine varied over $74-86 \%, 1.9-3.9 \mathrm{~mm}$ and 4.3-8.4 h, respectively. A 53-mm rainfall during the period of experiment $(41 \mathrm{~mm}$ in December and 12 $\mathrm{mm}$ in February) provided an effective rainfall of $5.02 \mathrm{~cm}$.

\section{Treatments and experimental design}

The experiment consisted of a single factor, irrigation water salinity. The treatments were $\mathrm{l}_{1}$ : irrigation by fresh water with a background EC of $0.385 \mathrm{dS} \mathrm{m}^{-1}$ (control) and $\mathrm{I}_{2}-\mathrm{I}_{5}$ : irrigation by saline water of EC 4 , 7,10 and $13 \mathrm{dS} \mathrm{m}^{-1}$, respectively. The experiment was laid out in a Randomized Complete Block Design (RCBD) with three replications. The plot size was $3 \mathrm{~m} \times 2 \mathrm{~m}$, buffer space between the adjacent plots was $1 \mathrm{~m}$ and that between the adjacent replications was $0.5 \mathrm{~m}$. Recommended fertilizer dose for wheat (120 $\mathrm{kg} \mathrm{N}, 32 \mathrm{~kg} \mathrm{P}, 62 \mathrm{~kg} \mathrm{~K}, 20 \mathrm{~kg} \mathrm{~S}, 3 \mathrm{~kg} \mathrm{Zn}$ and $1 \mathrm{~kg} \mathrm{~B} \mathrm{ha}^{-1}$ in the form of urea, triple super phosphate, muriate of potash, gypsum, zinc sulphate and borax, respectively; BARC, 2005) was used. Two-thirds of urea and the entire doses of other fertilizers were applied to the plots as a basal dose. The remaining urea was top-dressed at 20 days after sowing (DAS). Wheat seeds (cv. Shatabdi), @ $120 \mathrm{~kg} \mathrm{ha}^{-1}$ ) were sown at 2-3 cm depth in 20-cm apart rows on 24 November 2010. Weeds were uprooted when required. Prevalence of insect pests was controlled by spraying Bavistine and Ridomil Gold.

Irrigation was scheduled on the basis of growth stages of wheat: maximum tillering (35-40 DAS), booting (50-60 DAS) and milking/grain filling (75-85 DAS). Quantity of irrigation water was calculated by the difference in soil-water content at field capacity and that measured prior to application of irrigation for an effective root zone depth of $60 \mathrm{~cm}$. The field capacity of the soil was measured in situ before the first irrigation. The soil-water contents were measured with a Trime FM soil moisture meter (Eijkelkamp, The Netherlands). Saline water (for irrigation) was prepared by mixing sodium chloride (table salt) (@ 2.85, $5.08,7.31$ and $9.55 \mathrm{~g}$ salt per liter water) with fresh water that was pumped from a deep tubewell to obtain $4,7,10$ and $13 \mathrm{dS} \mathrm{m}^{-1}$ salinity $\left(\right.$ at $\left.25^{\circ} \mathrm{C}\right)$, respectively. Same amount of water was applied to each plot in a particular irrigation in check basins. Three irrigations, totaling $9 \mathrm{~cm}$ of water, were applied cautiously so that saline water did not adhere to the leaves of the crop. Leaf area index (LAI) and aboveground dry matter (ADM) of wheat was determined twice: at booting (49 DAS) and grain filling (90 DAS) stages. In order to measure the LAI and ADM of wheat, ten randomly selected plants from the buffer portion (area surrounding one square meter central portion) of each plot were clipped at the ground level 
on 49 and 90 DAS. The leaf blades were separated from the sheath at the collar and their areas were measured with a LI-3100 Leaf-Area Meter (LI-COR Biosciences, USA). The LAl for each plot was calculated by the ratio of the total leaf area in the sample plants to the average ground area occupied by them; the average ground area was calculated from the area of a plot and its plant population. The ADMs of the plots were determined by drying the stems and leaves of the sample plants in oven at $70^{\circ} \mathrm{C}$ for 72 $\mathrm{h}$. The yield and yield attributes were recorded. A combined analysis of variance of the growth and yield attributes, grain and biomass yields (sum of grain and straw yields), and harvest index ( $\mathrm{HI}$ ) of wheat was done for the RCB by using MSTAT-C (Russel and Eisensmith, 1983).

\section{Results and Discussion}

\section{Growth and yield attributes}

Plant height of wheat decreased from $75.4 \mathrm{~cm}$ under $I_{1}$ to $67.6 \mathrm{~cm}$ under $I_{5}$. It decreased by $0.7,2.2,9.3$ and $10.3 \%$ in $I_{2}, I_{3}, I_{4}$ and $I_{5}$, respectively compared to $I_{1}$. For irrigation water salinity $\leq 7 \mathrm{dS} \mathrm{m}^{-1}$, plant height was statistically similar; the higher salinity reduced plant height significantly $(p=0.05)$ compared to $\mathrm{I}_{1}$. Leaf area index, LAI, at 49 and 90 DAS decreased significantly as salinity of irrigation water increased except for $\mathrm{I}_{2}\left(4 \mathrm{dS} \mathrm{m}^{-1}\right)$ in which the LAl increased significantly compared to the other treatments (Table 1). This observation exposed that irrigation water salinity of $4 \mathrm{dS} \mathrm{m}^{-1}$ exerted a positive impact on leaf growth of wheat. Irrigation water salinity hindered tillering of wheat; the negative effect increased with the increase in salinity. Consequently, number of spikes per unit area (spike density) decreased as irrigation water salinity increased (Table 1). The largest spike density $\left(199 \mathrm{~m}^{-2}\right.$ ) was obtained under fresh water irrigation $\left(I_{1}\right)$ and, $I_{4}$ and $I_{5}$ produced significantly lower spike density compared to $I_{1}$. It is noted that salinity suppressed late tillering only since the first irrigation was applied at the maximum tillering stage. A reduced tiller density due to increased salinity of irrigation water was also reported by Chhipa and Lal (1995).

Table 1. Growth and yield attributes of wheat under five irrigation water salinities

\begin{tabular}{|c|c|c|c|c|c|c|c|c|}
\hline \multirow[t]{2}{*}{ Treatment } & \multirow{2}{*}{$\begin{array}{l}\text { Plant height } \\
(\mathrm{cm})\end{array}$} & \multicolumn{2}{|c|}{ Leaf area index } & \multirow{2}{*}{$\begin{array}{l}\text { Spike } \\
\left(\mathrm{m}^{-2}\right)\end{array}$} & \multirow{2}{*}{$\begin{array}{c}\text { Spike } \\
\text { length }(\mathrm{cm})\end{array}$} & \multirow{2}{*}{$\begin{array}{l}\text { Spikelet } \\
\left(\text { spike }^{-1}\right)\end{array}$} & \multirow{2}{*}{$\begin{array}{c}\text { Grain } \\
\left(\text { spike }^{-1}\right)\end{array}$} & \multirow{2}{*}{$\begin{array}{c}\text { 1000-grain } \\
\text { weight } \\
\text { (g) }\end{array}$} \\
\hline & & 49 DAS & 90 DAS & & & & & \\
\hline$I_{1}$ & $75.4^{\mathrm{a}}$ & $1.42^{\mathrm{a}}$ & $0.95^{a}$ & $206.0^{a}$ & $9.59^{a}$ & $19.5^{a}$ & $35.2^{a}$ & $54.7^{\mathrm{a}}$ \\
\hline $\mathrm{I}_{2}$ & $75.4^{\mathrm{a}}$ & $1.64^{b}$ & $1.12^{b}$ & $201.0^{a}$ & $9.86^{\mathrm{ab}}$ & $20.0^{\text {ab }}$ & $37.8^{\mathrm{a}}$ & $55.9^{\mathrm{ab}}$ \\
\hline$I_{3}$ & $73.8^{\mathrm{a}}$ & $1.32^{\mathrm{C}}$ & $0.71^{\mathrm{c}}$ & $198.3^{\mathrm{a}}$ & $9.10^{\mathrm{abc}}$ & $19.2^{\mathrm{abc}}$ & $34.1^{a b}$ & $53.2^{\mathrm{abc}}$ \\
\hline $\mathrm{I}_{4}$ & $68.4^{b}$ & $1.35^{\mathrm{d}}$ & $0.93^{\mathrm{d}}$ & $188.0^{b}$ & $8.74^{\mathrm{ac}}$ & $18.8^{\mathrm{acd}}$ & $30.8^{\mathrm{abc}}$ & $50.1^{\mathrm{ac}}$ \\
\hline$I_{5}$ & $67.6^{b}$ & $0.96^{\mathrm{e}}$ & $0.46^{\mathrm{e}}$ & $182.3^{\mathrm{C}}$ & $8.31^{\mathrm{c}}$ & $17.9^{\mathrm{d}}$ & $29.7^{b c}$ & $47.8^{\mathrm{C}}$ \\
\hline $\mathrm{LSD}_{0.05}$ & 3.15 & 0.03 & 0.02 & 14.22 & 0.99 & 1.11 & 4.98 & 5.23 \\
\hline
\end{tabular}

Common letter(s) within the same column do not differ significantly at $5 \%$ level of significance

Salinity of irrigation water $>4 \mathrm{dS} \mathrm{m}^{-1}$ exerted a negative impact on spike length, number of spikelets and grains per spike, and 1000-grain weight of wheat. These yield attributes continued decreasing with the increase in salinity of irrigation water (Table 1). It is remarkable that $\mathrm{I}_{2}\left(4 \mathrm{dS} \mathrm{m}^{-1}\right)$ enhanced, although insignificantly, all these yield attributes over the control treatment. The spike length decreased by 6.9, 10.5 and $15.0 \%$ under $I_{3}, I_{4}$ and $I_{5}$, respectively but increased by $0.9 \%$ under $I_{2}$ compared to $I_{1}$. Treatments $I_{1}-I_{4}$ produced indifferent spike lengths while $I_{5}$ produced significantly smaller spike length than $I_{1}$ and $I_{2}$. $I_{1}-I_{4}$ produced identical number of spikelets and grains per spike, and 1000-grain weight, while $I_{5}$ produced significantly lower values of these yield attributes compared to $I_{1}$. The number of spikelets per spike decreased by $1.7,3.7$ and $8.3 \%$ under $I_{3}, I_{4}$ and $I_{5}$, respectively, but increased by $2.6 \%$ under $I_{2}$ over $I_{1}$, indicating a systematic decrease in spikelets with the increase in salinity of irrigation water. The number of spikelets per spike was a function of spike length; the larger the spike length, the higher was the number of spikelets per spike. Number of grains per spike decreased by $3.2,12.4$ and $16.7 \%$ under $I_{3}$, $I_{4}$ and $I_{5}$, respectively but increased by $7.4 \%$ under $I_{2}$ compared to $I_{1}$. The number of grains per spike was 
therefore very sensitive to salinity of irrigation water $\geq 7 \mathrm{dS} \mathrm{m}^{-1}$. Although Behrouz et al. (2009) obtained a significantly different 1000-grain weight, plant height, spike length and LAl of wheat under irrigation water of salinity 2,8 and $12 \mathrm{dS} \mathrm{m}^{-1}$, significantly reduced values of these crop attributes only for irrigation water salinity $\geq 10 \mathrm{dS} \mathrm{m}^{-1}$ were obtained during this study.

\section{Above-ground dry matter}

Above-ground dry matter, ADM, of wheat at 49 and 90 DAS decreased significantly as irrigation water

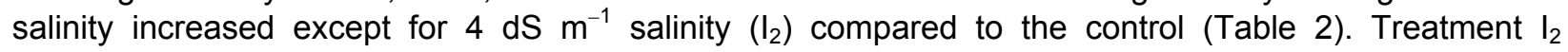
augmented ADM and, consequently, provided the utmost and significantly larger ADMs compared to the other treatments at both stages of the crop. A positive impact of salinity on AMD was also reported by AlSaadi et al. (1982) who observed significant increase in plant dry matter of wheat at $6.8 \mathrm{dS} \mathrm{m}^{-1}$ soil salinity. At 49 DAS, ADM decreased by $13.0,19.4$ and $29.6 \%$ under $I_{3}, I_{4}$ and $I_{5}$, respectively compared to the control. At 90 DAS, the decrease in ADM of $6.1,8.4$ and $34.8 \%$, under the corresponding treatments demonstrated an extensive negative impact of 7,10 and $13 \mathrm{dS} \mathrm{m}^{-1}$ salinities of irrigation water on ADM production.

Table 2. Yield and water productivity of wheat under five irrigation water salinities

\begin{tabular}{|c|c|c|c|c|c|c|c|c|}
\hline Treatment & \multicolumn{2}{|c|}{$\begin{array}{c}\text { Above-ground dry } \\
\text { matter }\left(\mathrm{t} \mathrm{ha}^{-1}\right)\end{array}$} & $\begin{array}{c}\text { Grain yield } \\
\left(\mathrm{t} \mathrm{ha}^{-1}\right)\end{array}$ & $\begin{array}{c}\text { Straw } \\
\text { yield } \\
\left(\mathrm{t} \mathrm{ha}^{-1}\right)\end{array}$ & $\begin{array}{c}\text { Biomass } \\
\text { yield } \\
\left(\mathrm{t} \mathrm{ha}^{-1}\right)\end{array}$ & $\begin{array}{c}\text { Grain- } \\
\text { straw } \\
\text { ratio }\end{array}$ & $\begin{array}{c}\text { Water } \\
\text { productivity for } \\
\text { grain } \\
\left(\mathrm{kg} \mathrm{ha}^{-1} \mathrm{~cm}^{-1}\right)\end{array}$ & $\begin{array}{c}\text { Water } \\
\text { productivity for } \\
\text { biomass } \\
\left(\mathrm{kg} \mathrm{ha}^{-1} \mathrm{~cm}^{-1}\right)\end{array}$ \\
\hline $\mathrm{I}_{1}$ & $2.26^{\mathrm{a}}$ & $5.21^{\mathrm{a}}$ & $3.847^{\mathrm{a}}$ & $5.085^{\mathrm{a}}$ & $8.932^{\mathrm{a}}$ & $0.76^{\mathrm{a}}$ & $192.1^{\mathrm{a}}$ & $254.0^{\mathrm{a}}$ \\
\hline $\mathrm{I}_{2}$ & $2.76^{\mathrm{b}}$ & $6.54^{\mathrm{b}}$ & $3.820^{\mathrm{a}}$ & $4.797^{\mathrm{ab}}$ & $8.617^{\mathrm{ab}}$ & $0.80^{\mathrm{a}}$ & $190.8^{\mathrm{a}}$ & $239.6^{\mathrm{ab}}$ \\
\hline $\mathrm{I}_{3}$ & $7.75^{\mathrm{c}}$ & $4.73^{\mathrm{c}}$ & $3.683^{\mathrm{a}}$ & $4.220^{\mathrm{bc}}$ & $7.903^{\mathrm{abc}}$ & $0.87^{\mathrm{a}}$ & $184.0^{\mathrm{a}}$ & $210.8^{\mathrm{bc}}$ \\
\hline $\mathrm{I}_{4}$ & $1.77^{\mathrm{d}}$ & $4.86^{\mathrm{d}}$ & $3.257^{\mathrm{ab}}$ & $4.060^{\mathrm{bcd}}$ & $7.317^{\mathrm{bc}}$ & $0.80^{\mathrm{a}}$ & $162.7^{\mathrm{ab}}$ & $202.8^{\mathrm{c}}$ \\
\hline $\mathrm{I}_{5}$ & $1.57^{\mathrm{e}}$ & $3.33^{\mathrm{e}}$ & $2.947^{\mathrm{b}}$ & $3.991^{\mathrm{cd}}$ & $6.938^{\mathrm{c}}$ & $0.74^{\mathrm{a}}$ & $147.2^{\mathrm{b}}$ & $199.4^{\mathrm{c}}$ \\
\hline $\mathrm{LSD}_{0.05}$ & 0.026 & 0.02 & 0.690 & 0.735 & 1.250 & 0.16 & 34.49 & 36.71 \\
\hline
\end{tabular}

Common letter(s) within the same column do not differ significantly at $5 \%$ level of significance

\section{Yields and water productivity}

Irrigation by fresh water $\left(I_{1}\right)$ helped producing paramount grain, straw and biomass yields and that by high saline water $\left(13 \mathrm{dS} \mathrm{m}^{-1} ; I_{5}\right.$ ) suppressed them to the lowest values followed by $T_{4}$ (Table 2 ). Under $I_{2}-I_{5}$, the grain yield decreased by $0.7,4.3,15.3$ and $23.4 \%$, respectively compared to $I_{1}$. These results are in agreement with the findings of Chauhan et al. (1991), but in contradiction, to some extent, with Phogat et al. (2001), who obtained 32 and $63 \%$ reduced grain yield of wheat under 8 and $12 \mathrm{dS} \mathrm{m}^{-1}$ salinity, respectively compared to the non-saline treatment. Flagella et al. (2000), on the contrary, found significant damages of wheat only with irrigation water salinity of $12 \mathrm{dS} \mathrm{m}^{-1}$ or more. Salinity level $\leq 7 \mathrm{dS}$ $\mathrm{m}^{-1}$ exerted insignificant impact on the grain yield of wheat. $I_{1}-I_{4}$ produced statistically similar grain yields, but $I_{5}$ produced a significantly reduced grain yield. The grain yields under $I_{4}$ and $I_{5}$ were similar. These results are in partial agreement with that of Yazar et al. (2003), who obtained similar grain yields of wheat under $0.5,3.0,6.0,9.0$ and $12.0 \mathrm{dS} \mathrm{m}^{-1}$ irrigation water salinity levels. Chauhan et al. (1991) reported obtaining $90 \%$ or more of the optimum yield of wheat under two supplemental irrigations with water salinity $8-12 \mathrm{dS} \mathrm{m}^{-1}$. It is therefore contemplated that if saline water is used only for supplemental irrigations, wheat might provide acceptable yield under higher salinity level. The straw yield of wheat reduced by $3.5,11.5,18.0$ and $22.3 \%$ under $I_{2}, I_{3}, I_{4}$ and $I_{5}$, respectively compared to $I_{1} . I_{1}$ and $I_{2}$ produced invariant straw yields, while $I_{3}-I_{5}$ produced similar but significantly lower straw yields than $I_{1}$. Although Behrouz et al. (2009) obtained significantly different grain and straw yields under irrigation water salinity of 2, 8 and $12 \mathrm{dS} \mathrm{m}^{-1}$, significantly different values of these yields for irrigation water salinities 4 and 13

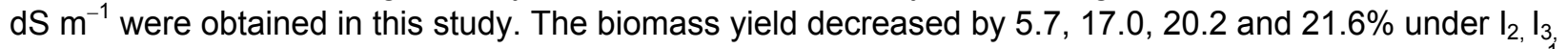
$I_{4}$ and $I_{5}$, respectively compared to $I_{1}$. It is noted that although irrigation water salinity of $4 \mathrm{dS} \mathrm{m}^{-1}$ augmented most of the growth and yield attributes of wheat, it suppressed tillering and hence spike 
density, which, consequently, reduced the grain, straw and biomass yields of the crop. The ratios of the grain to straw yields were similar in all treatments (Table 2). The highest value (0.87) was under $I_{3}$ and the lowest $(0.74)$ was under $I_{5}$. The grain-straw ratios revealed that irrigation water salinity of $13 \mathrm{dS} \mathrm{m}^{-1}$ retarded the grain yield more than the straw yield. The production function of wheat, estimated under conditions of the imposed irrigation water salinities $\left(0.385,4,7,10\right.$ and $\left.13 \mathrm{dS} \mathrm{m}^{-1}\right)$, followed a quadratic form. This function depicted that as salinity level of irrigation water increased, the yield level of wheat decreased. This result is in full agreement with that of Data et al. (1998). Water productivity for grain production under the treatments synchronized with grain yield of the corresponding treatments. For biomass production, water productivities under $I_{1}$ and $I_{2}$ were similar but significantly higher than that under $\mathrm{I}_{4}$ and $\mathrm{I}_{5}$, which provided similar water productivities.

\section{Conclusion}

Irrigation by saline water of electrical conductivity 10 and $13 \mathrm{dS} \mathrm{m}^{-1}$ (at $25^{\circ} \mathrm{C}$ ) significantly $(\mathrm{p}=0.05)$ suppressed most growth and yield attributes, and yield of wheat compared to irrigation by fresh water of

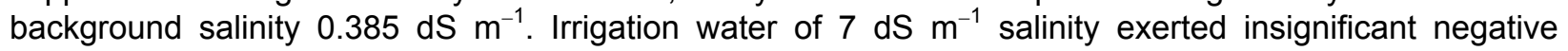
impact on the crop attributes except for leaf area index, above ground dry matter, straw yield and water productivity for straw production. Irrigation water salinity of $4 \mathrm{dS} \mathrm{m}^{-1}$ improved leaf area index, spike length, spikelets and grains per spike, 1000-grain weight and above-ground dry matter compared to irrigation by fresh water. Because of the largest spike density arising from the highest tiller density, irrigation by fresh water provided higher, although statistically alike, grain, straw and biomass yields than irrigation by saline water of $4 \mathrm{dS} \mathrm{m}^{-1}$. It is, nevertheless, speculated that there might be some advantageous level of irrigation water salinity for wheat cultivation. Further study is needed to verify this supposition and establish the fact taking into account the ensuing salt dynamics in the irrigated soil.

\section{References}

Aldesuquy, H.S. and Ibrahim, A.H. 2002. Water relations, abscisic acid and yield of wheat plants in relation to the interactive effect of seawater and growth bioregulators. J. Agron. Crop Sci., 187: 97-104.

Allen, R.G., Pereira, L.S., Raes, D. and Smith, M. 1998. Crop evapotranspiration: Guideline for computing crop water requirements. Irrigation and Drainage Paper no. 56, FAO, Rome, Italy.

Al-Saadi, H.A., Al-Mousawi, H.A. and El-Hytemy, Y.Y. 1982. Effect of interaction between salinity and nitrogen applications on wheat growth. Bangladesh J. Bot., 11: 64-72.

BARC (Bangladesh Agricultural Research Council). 2005. Soil fertility status of different agro-ecological zones, BARC Soils Publication No. 45: 15-32.

Behrouz, M., Hamed, M., Mousavi, S.F. and Feizi, M. 2009. Effects of different levels of irrigation water salinity and leaching on yield and yield components of wheat in an arid region. J. Irrig. Drain. Eng., 135: 1-32.

Chauhan, C.P.S., Singh, R.B., Minhas, P.S., Agnihotri, A.K. and Gupta, R.K. 19912003. Response of wheat to irrigation by saline water varying in anionic constituents and phosphorus application. Agric. Water Manage., 20: 223-231.

Chhipa, B.P. and Lal, P. 1995. Effect of soil salinity on yield, yield attributes and nutrient uptake by different varieties of wheat. Annual de Edafologia, 44: 1681-1691.

Data, K.K., Sharma, V.P. and Sharma, D.P. 1998. Estimation of a production function for wheat under saline conditions. Agric. Water Manage., 36: 85-94.

Flagella, Z., Vittozzi, L.C., Platini, C. and Fonzo, N.D. 2000. Effect of salt stress on photosynthesis electron transport and grain yield in durum wheat (Triticum durum). Proceeding of the conference on Irrigation Research: Process in the use of water resources, Bari, Italy, 47: 31-36.

Flowers, T.J., Ragab, R., Malash, N., Gawad, G.A., Guartero, J. and Arslan, A. 2005. Sustainable strategies for irrigation in saltprone Mediterranean: SALTMED. Agric. Water Manage., 78: 3-4

Ghane, E., Behrouz, M., Feizi, M. and Esmail, L. 2011. Effect of water quality and different planting methods on wheat yield. J. Communic. Soil Sci. Plant Anal., 42: 369-380.

Gupta, S.R. and Gupta, C.I. 1987. Management of saline soil and water of India. Moganprimalahi for Oxford and IBH publishing Co. Pvt. Ltd. New Delhi. 
Hamdy, A. 1995. Saline water use and management for sustainable agriculture in the Mediterranean region. Proceeding of Workshop On-farm Sustainable Use of Saline Water in Irrigation: Mediterranean Experiences, 5-8 October, Hammamet, Tunisia.

Hamdy, A. 1996. Use of unconventional water resources as a fresh water saving practice. Proceeding of $16^{\text {th }}$ Congress on Irrigation and Drainage, ICID and CHIEAM-IAM-B, Cairo, Egypt.

Heidarpour, M., Mostafazadeh-Fard, B., Arzani, A., Aghakhani, A. and Feizi, M. 2009. Effects of irrigation water salinity and leaching fraction on yield and evapotranspiration in spring wheat. J. Communic. Soil Sci. Plant Anal., 40: 2521-2535.

Mojid, M.A., Biswas, S.K. and Wyseure, G.C.L. 2012. Interaction effects of irrigation by municipal wastewater and inorganic fertilizers on wheat cultivation in Bangladesh. Field Crops Res., 134: 200-207.

Phogat, V., Satyawan, S., Kumar, S., Sharma, S.K., Kapoor, A.K. and Kuhal, M.S. 2001. Performance of upland cotton and wheat genotypes under different salinity conditions. Indian J. Agric. Sci., 71: 303-305.

Rahman, S.M., Khalil, M.I. and Ahmed, M.F. 1995. Yield-water relations and nitrogen utilization by wheat in salt-affected soils of Bangladesh. Agric. Water Manage., 28: 49-56.

Rhoades, J.D., Kandiah, A. and Mashali, A.M. 1992. The use of saline water for crop production. FAO Irrigation and Drainage Paper no. 48, FAO, Rome, Italy.

Russell, D.F. and Eisensmith, S.P. 1983. MSTAT-C. Crop Soil Science Department, Michigan State University, USA.

Shalhevet, J. 1994. Using water of marginal quality for crop production: Major issues - Review article. Agric. Water Manage., 25: 233-269.

Steppuhn, H., van Genuchten, M.T. and Grieve, C.M. 2005. Root-zone salinity: selecting a product-yield index and response function for crop tolerance. J. Crop. Sci., 45: 209-220.

UNDP (United Nations Development Prograramme) and FAO (Food and Agriculture Organization). 1988. Land Resources Appraisal of Bangladesh for Agricultural Development. Report 2. Agro-ecological Regions of Bangladesh. United Nations Development Programme, Food Agric. Orgn., 212-221pp.

Yazar, A., Hamdy, A., Gencel, B., Sezen, M.S., Kocc, M. 2003. Wheat yield response to irrigation by saline water under the Mediterranean climatic conditions in Turkey. Sustainable Use of Highly Saline Water for Irrigation of Crops under Arid and Semi-Arid Conditions: New Strategies. Çukurova University, Adana, Turkey.

Zaire, K.P.P. and Khuble, N.C. 1990. Different response of wheat and barley genotypes substrate induced salinity under North Indian conditions. Exp. Agric., 26: 221-225. 